Vol. I No. 2 - August 2020

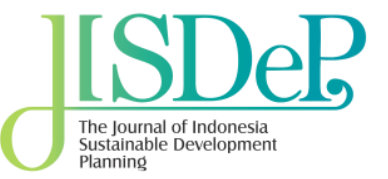

E-ISSN: $\underline{2722-0842}$ | P-ISSN: $\underline{2721-8309}$

Available online at

http://journal.pusbindiklatren.bappenas.go.id/

\title{
Sustainable Development of Energy Supply Planning For Productive Economy in Isolated Island
}

\author{
Moristanto ${ }^{1}$ and Guntur Tri Setiandanu ${ }^{2}$ \\ Research and Development Centre for Electricity Renewable Energy and Conservation Technology \\ Bogor, Indonesia ${ }^{1,2}$ \\ moristanto@esdm.go.id; guntur.setiadanu@esdm.go.id
}

\begin{abstract}
This paper describes the sustainable development of energy supply planning for productive economy in border, small, and isolated island using case study in the region of Sitaro Island, North Sulawesi. This paper describes that energy supply planning must be sufficient, secure, reliable, and affordable for users by using local potency of energy resources that are renewable and unlimited. The paper identifies local energy potential demand of energy, current productive economy, current system of electricity, and infrastructure of energy. It finds that the local potential of energy resources is photovoltaic. The demand of energy of Islands is primary for lighting, ironing, and entertainment. The existing economy of islands is dominated by fisheries, agriculture, and tourism. The total of electricity generated is about $6.000 \mathrm{~kW}$ that is all supplied using PLTD. The infrastructure of energy is covered by PLN using 4 system of distributions that are System of Siau, System of Makalehi, System of Tagulandang dan System of Biaro. The local government is concerning to build up industrial cluster of fisheries for domestic and abroad markets and also to create the exotics tourism. With a serious commitment and high awareness among government, industries, and society, it is possible to increase the economy and social welfare because they have enough energy potential, abundant fish in the sea, and good tourism prospect in the future. It concludes that the energy supply should meet the demand sufficiently, securely, reliably, and affordably. In terms of productive economy, the energy should create the value added in society and increase the welfare. It recommends that in the border, small, and isolated island, the abundant and renewable of energy resources, photovoltaic, can be substituted to PLTD. Since it is only available in daylight. In order to make it useful in midnight, we need a power storage as a back-up of energy resources.
\end{abstract}

Keywords: planning, energy, resources, productive and economy

ARTICLE INFO
Received: June 22, 2020
Received in revised form: August 20,
2020
Accepted: August 24, 2020

Accepted: August 24, 2020

doi: 10.46456/jisdep.v1i2.71
JISDeP - The Journal of Indonesia Sustainable Development Planning Published by Centre for Planners' Development, Education, and Training (Pusbindiklatren),

Ministry of National Development

Planning/ National Development

Planning Agency (Bappenas), Republic

of Indonesia
Address: Jalan Proklamasi 70,

Central Jakarta, Indonesia 10320

Phone: +62 $2131928280 / 3192828$

Fax: +622131928281

E-mail: pusbindiklatren@bappenas.go.id

Supported by Indonesian Development Planners Association (PPPI) 


\section{Introduction}

One of the main current issues in the development of small islands is the limited basic infrastructure of the community (Marulitua et.al, 2019). The intended infrastructure includes the availability of social and economic facilities such as electricity, clean water, fuel and fisheries facilities. Although the government has various interventions, the needs and problems of small islands are very complex and need a cross-sectoral approach to deal with them. Problems in the management of facilities and infrastructure on small islands are related to the institutional capacity of the community and the support of local government. Islands Economic Development must be based on the biophysical conditions of the region and the island's socio-economic conditions. Like small islands, they will be vulnerable to environmental changes caused by the construction of living facilities. Therefore, the development carried out must consider the environment. In an effort to achieve economic development on the leading islands, the researcher of Research and Development Centre for Electricity Renewable Energy and Conservation Technology examines the development of renewable energy for productive economic activities on the leading islands. The study indicates the productive potential of the economy needs to be supported by new renewable energy that locally available. The hybrid scenario between conventional plants (PLTD, PLTU, PLTG) and new renewable energy plants (PLTS, PLTMH, Biomass) is expected to be a solution for the development of electricity in small islands. Based on the previous study of productive economic fisheries, the development of centralized solar power plants using batteries or hybrids with diesel-fired diesel generators on small islands is the best solution as local energy utilization.

This paper describes the energy supply planning for productive economy in border, small, and isolated island using case study in the region of Sitaro Island, North Sulawesi. The purpose of this paper is that energy supply planning is created to fulfill the demand of energy with sufficient, secure, reliable, and affordable for users by using local potency of energy resources that are renewable and unlimited. The paper identifies local energy potential demand of energy, current productive economy, current system of electricity, and infrastructure of energy.

\section{Methodology}

The methodology of this paper is on site survey and collecting primary and secondary data ini Sitaro Island. Those data are processed using analytical data by PVSyst and meteonorm software. PVSyst provides performance assessment of a simulation model for PV modules of any available technology. Meteonorm provides data of Irradiation and other climate data for any location on earth as typical years. Primary data is collected using interview and secondary data is based on latest data in Central Bureau of Statistics. The cost of PLTS hybrid energy is calculated using the Life Cycle Analysis (LCA) method. The LCA is a method used to evaluate the environmental impact of a product through its life cycle encompassing extraction and processing of the raw materials, manufacturing, distribution, use, recycling, and final disposal. It calculates a comparison of the total cost used to produce energy with the amount of energy produced during the life of the PLTS.

The paper analysis what local energy potential resources, quantify the demand of energy, analysis current productive economy that is the top three of the largest Gross Domestic Product (GDP), the existing system of electricity, and infrastructure of energy. The top three of GDP is focused to develop as main issues of productive economy. The existing system of electricity as baseline of the supply of energy infrastructure. Those data are combined and evaluated in order to meet that energy supply planning should be sufficient, secure, reliable, and affordable for users or demand of energy from now and further.

\section{Results and Discussions}

The location of this research activity was carried out in one outermost districts in North Sulawesi province, namely Kabupaten Sitaro Islands (Siau Tagulandang Biaro) which borders directly and has international waters boundaries with Davao del Sur province, Philippines. This district was the expansion of the Sangihe and Talaud Islands Districts, where Kab. Talaud blooms in 2000, and Kab. Sitaro bloomed in 2007, while Sangihe is the parent district of the island region (BPS, 2020). 


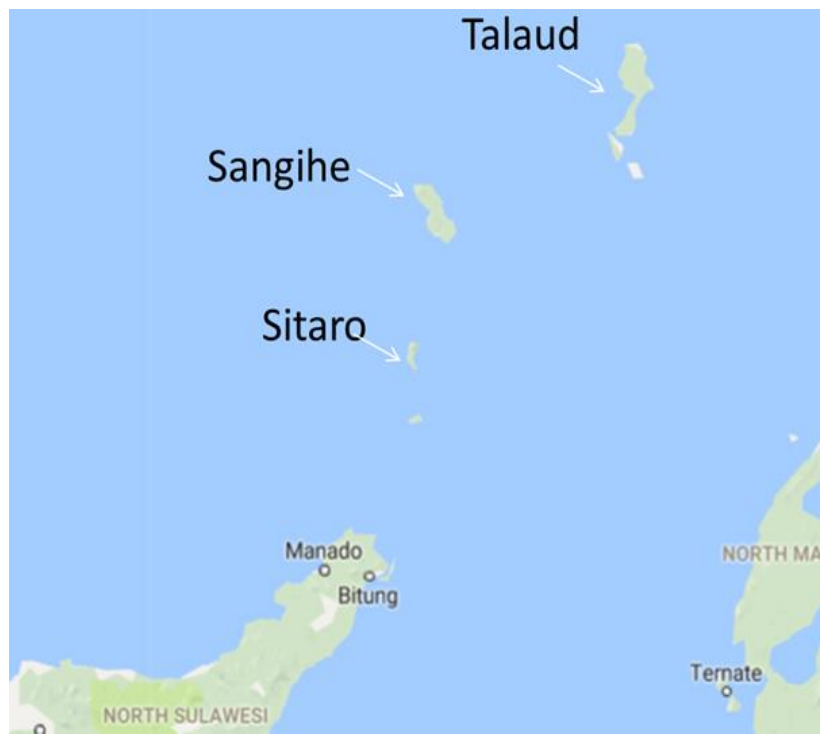

Figure 1. Region of Siau Tagulandang Biaro Island in North Sulawesi

Source: BPS, 2020

\section{System of Electricity in Sitaro Islands}

System of electricity in Sitaro Islands is provided by PT. PLN Branch Tahuna, Siau and Tagulandang. It consists of four electricity systems namely Siau System, Makalehi System, Tagulandang System and Biaro System. Electricity system in Sitaro is powered by diesel power generation (Pembangkit Listrik Tenaga Diesel - PLTD in Indonesia language), both PLTD owned by PLN and PLTD rented by Independent Power Producers (IPP). Only one Solar Energy System (PLTS) is located in Makalehi system with 260 kW capacity. Totally, system of electricity in Sitaro Islands had installed capacity 11,610 kW.

\section{Potency and Future Planning of Productive Economy in Sitaro Islands}

The potential economy in Sitaro Islands is captured by fisheries, plantations and tourism. In 2019 there were 2,538 fisheries businesses, which were fishing with various types of equipment and vehicles as presented in the table 1 below.

Table 1. Various types of vehicle and equipment of Fisheries in Sitaro Island

\begin{tabular}{|c|c|c|c|c|c|c|c|}
\hline \multirow{2}{*}{ Year } & \multicolumn{4}{|c|}{ Non Motorized Vessels } & \multirow{2}{*}{ Out-Board Motor Boat } & \multirow{2}{*}{ In Board Motor Boat } & \multirow{2}{*}{ Total } \\
\hline & Jukung & Small & Medium & Large & & & \\
\hline 2015 & 70 & 418 & 81 & 17 & 2885 & 28 & 3499 \\
\hline 2016 & 70 & 499 & 100 & 14 & 2920 & 43 & 3646 \\
\hline 2017 & 70 & 584 & 120 & 14 & 3219 & 85 & 4092 \\
\hline 2018 & 0 & 499 & 13 & 14 & 1332 & 15 & 1873 \\
\hline 2019 & 316 & 0 & 0 & 0 & 2179 & 43 & 2538 \\
\hline
\end{tabular}

The potential of plantation products in Sitaro Islands is quite large, especially in 3 types of plantations, namely Nutmeg, Coconut and Cloves. The area of land and the amount of plantation production based on BPS data in 2019 shows that coconut and nutmeg plants are still the dominant of the community in plantations. As presented in Table 2 below, the area of coconut reaches 4435.05 hectares with production of 3239.88 tons, while Pala has a land area of 4619.13 hectares with production of 3207.85 tons. From data on land area and plantation production per sub-district, it can be seen that the main centers of plantation crops are still on Siau Island, although for coconut plants, Tagulandang Island is also the main center because it is known as a coconut producer. However, because the area of Tagulandang island is not too large, it is difficult to increase the area of plantations in Tagulandang Island. 
Table 2. The production of Plantation in Sitaro Islands

\begin{tabular}{lrrrrrr}
\hline \multirow{2}{*}{ Subdistrict } & \multicolumn{2}{c}{ Coconut } & \multicolumn{2}{c}{ Clove } & \multicolumn{2}{c}{ Nutmeg } \\
\cline { 2 - 7 } & $\mathbf{2 0 1 8}$ & $\mathbf{2 0 1 9}$ & $\mathbf{2 0 1 8}$ & $\mathbf{2 0 1 9}$ & $\mathbf{2 0 1 8}$ & $\mathbf{2 0 1 9}$ \\
\hline Biaro & 203.1 & 203.1 & 70.07 & 38.22 & 41.93 & 41.93 \\
\hline Tagulandang Selatan & 711.98 & 711.98 & $\mathbf{4 7 . 6 5}$ & $\mathbf{4 7 . 6 5}$ & 363.55 & 363.55 \\
\hline Tagulandang & 857.9 & 857.9 & 51.84 & 51.84 & 413.36 & 533.36 \\
\hline Tagulandang Utara & 485.69 & 485.69 & 37.02 & 37.02 & 243.45 & 243.45 \\
\hline Siau Barat Selatan & 345.8 & 345.8 & 19.83 & 19.83 & 438.27 & 438.27 \\
\hline Siau Timur Selatan & 339.35 & 339.35 & 33.06 & 33.06 & 511.14 & 511.14 \\
\hline Siau Barat & 354.1 & 354.1 & 48.92 & 48.92 & 508.2 & 508.2 \\
\hline Siau Tengah & 225.8 & 225.8 & 32.12 & 32.12 & 342.33 & 342.33 \\
\hline Siau Timur Selatan & 436.18 & 436.18 & 43.97 & 43.97 & 944.05 & 944.05 \\
\hline Siau Barat Utara & 475.15 & 475.15 & 117.64 & 117.64 & 692.85 & 692.85 \\
\hline Total & $\mathbf{4 4 3 5 . 0 5}$ & $\mathbf{4 4 3 5 . 0 5}$ & $\mathbf{5 0 2 . 1 2}$ & $\mathbf{4 7 0 . 2 7}$ & $\mathbf{4 4 9 9 . 1 3}$ & $\mathbf{4 6 1 9 . 1 3}$ \\
\hline \multicolumn{3}{c}{ Source: BPS, 2020} & & &
\end{tabular}

Potency of tourism in Sitaro Islands is very large, but the management, tourism facilities and infrastructure are still left behind. Tourism data shows that during 2019 the number of tourist visits to Sitaro was 2440 people consisting of 2161 domestic tourists and 279 foreign tourists from several countries such as the United States, Canada, England, Germany, France, Russia, China, Japan etc. This number continues to increase from year to year as shown in Table 3 below. However, this number is still very small compared to more famous tourist destinations such as Bunaken in Manado with totally 87312 tourists in 2019, even though there are many comments from tourists, the coral reefs of Sitaro are more beautiful than Bunaken.

Table 3. The number of Tourists visits Sitaro Islands

\begin{tabular}{ccc}
\hline Tahun & Domestic Tourists & Foreign Tourists \\
\hline 2015 & 1.196 & 228 \\
\hline 2016 & 1.268 & 235 \\
\hline 2017 & 2.776 & 462 \\
\hline 2018 & 2.120 & 556 \\
\hline 2019 & 2.161 & 279 \\
\hline
\end{tabular}

Source: BPS, 2020

Model of Infrastructure Energy in Sitaro Islands

The figure 2 shows the profile of energy demand for fisheries product in Sitaro Islands. We can get data for processing centers and cold chain systems in Sitaro island need $2538 \mathrm{kWh} /$ day. This profile describes the energy demand in along day. It clearly shows a peak load of $146 \mathrm{~kW}$.

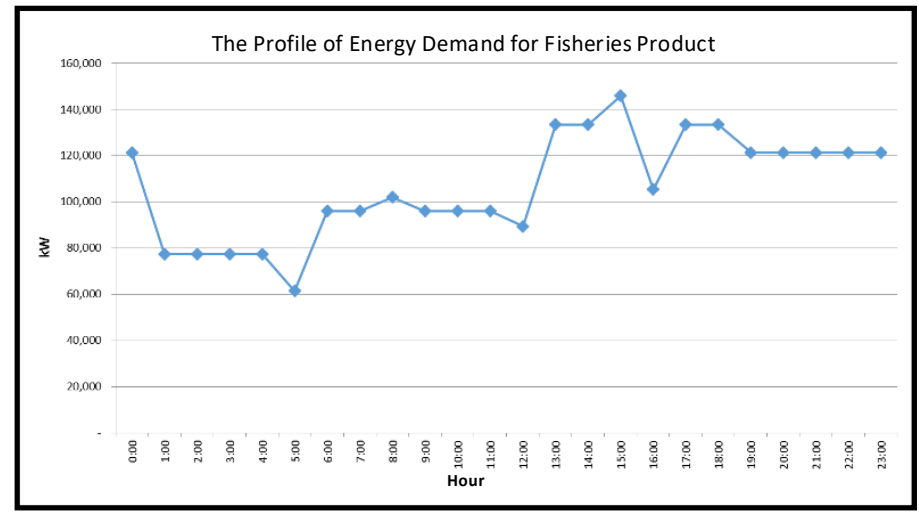

Figure 2. The profile of energy demand for plantation product in Sitaro Islands. 
Table 5 shows the profile of energy demand for plantation product. Mainly, the energy demand comes from Drier of Pala with totally consumes $1152 \mathrm{~kW} /$ day, Blower and Compressor consume $230 \mathrm{kWh} /$ day, and Shell Breaker consumes $157 \mathrm{kWh} /$ day. Therefore, in overall we can get data for processing centers of plantations in Sitaro islands need 1540 kWh / day with a peak load of $128 \mathrm{~kW}$.

Table 5. Detail Profile of Plantation Electricity Demand

\begin{tabular}{|c|c|c|c|c|c|c|c|c|c|c|c|c|}
\hline \multirow{2}{*}{ No } & \multirow{2}{*}{ Equipment } & \multicolumn{3}{|c|}{ Capacity } & \multirow{2}{*}{ Component } & \multirow{2}{*}{$\begin{array}{c}\text { Power } \\
\text { per } \\
\text { Unit }\end{array}$} & \multirow{2}{*}{$\begin{array}{l}\text { Total } \\
\text { Power }\end{array}$} & \multirow{2}{*}{$\begin{array}{c}\text { Work } \\
\text { hour/ } \\
\text { day }\end{array}$} & \multicolumn{3}{|c|}{$\begin{array}{c}\text { Total Demand of } \\
\text { Energy }\end{array}$} & \multirow{2}{*}{$\begin{array}{c}\text { Unit P rice, } \\
\text { Rp }\end{array}$} \\
\hline & & $\begin{array}{l}\text { Unit of } \\
\text { Capacity }\end{array}$ & Number & $\begin{array}{l}\text { Ton/ } \\
\text { hour }\end{array}$ & & & & & $\begin{array}{l}\text { Per } \\
\text { Hour }\end{array}$ & \begin{tabular}{|c|} 
Per \\
Month
\end{tabular} & $\begin{array}{l}\text { Per } \\
\text { Year }\end{array}$ & \\
\hline 1 & $\begin{array}{l}\text { Drier Chamber of } \\
\text { Nutmeg } 10 \text { Ton/cycle }\end{array}$ & 10 Ton/week & 6 & 8.57 & Heater Coil & 16 & 96 & 12 & 1,152 & 34,560 & 414,720 & $130,000,000$ \\
\hline & & & & & Blower & 0.3 & \multirow{3}{*}{9.6} & \multirow{3}{*}{10.6} & \multirow{3}{*}{230} & & & \\
\hline & & & & & Kompressor & 0.3 & & & & & & \\
\hline & & & & & Motor & 1 & & & & & & \\
\hline 2 & Shell Breaker & $200 \mathrm{~kg} / \mathrm{hour}$ & 6 & 8.4 & Motor & 3.73 & 22.38 & 7 & 157 & 3,133 & 37,598 & $60,000,000$ \\
\hline \multirow{2}{*}{\multicolumn{7}{|c|}{ Total Capacity of Energy }} & 127.98 & & 1,539 & 37,693 & 452,318 & \\
\hline & & & & & & & 128 & kW & 1,540 & $\mathrm{kWh} / \mathrm{da}$ & & \\
\hline
\end{tabular}

The figure 3 shows the profile of energy demand for hotels product in Sitaro Islands. From the profile, we can get data for operating hotels in Sitaro islands need $7946.27 \mathrm{kWh} /$ day with a peak load of 569.15 $\mathrm{kW}$

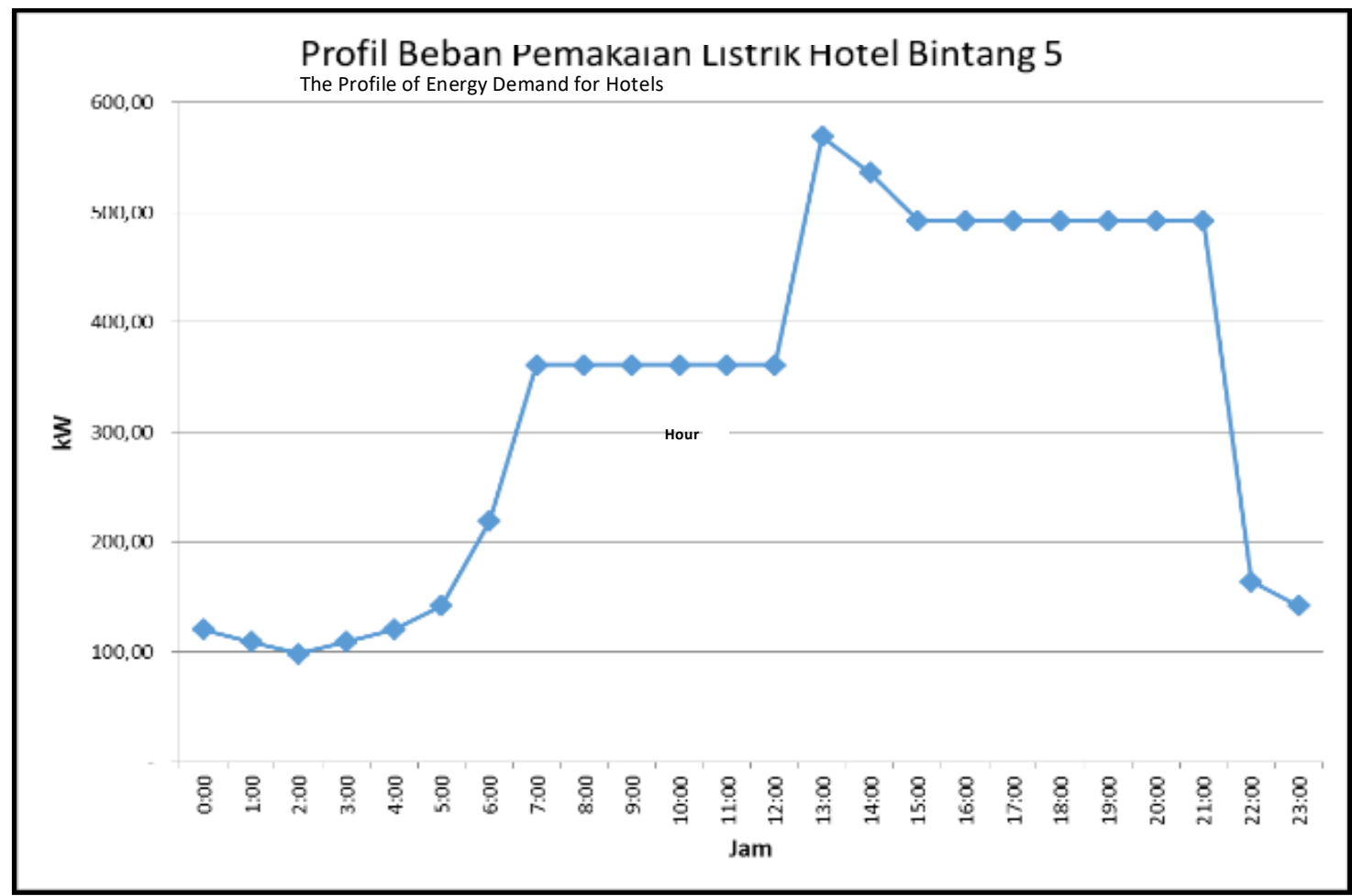

Figure 3. The profile of energy demand for hotels

Total demand of electricity from fisheries, plantation, tourism, and customers seen in table 6 . Assuming that the growth of the electricity demand from non-productive economy is supplied by the PLN power plant reserves, the addition of the electricity demand from the productive economic and their growth must be considered for the addition of the power plant. Addition of power plants must consider availability from fuel sources. Currently, the existing conditions the only available fuel source is diesel oil (PLTD), while for Renewable energy that available is solar energy. Therefore, the generation scenarios that can be used are hybrid generation between PLTS and PLTD. 
Table 6. Demand of Electricity

\begin{tabular}{cccc}
$\begin{array}{c}\text { Load of Productive } \\
\text { Economy }\end{array}$ & $\begin{array}{c}\text { Demand of Power, } \\
\text { kW }\end{array}$ & $\begin{array}{c}\text { Demand of Energy, } \\
\text { kWh }\end{array}$ & $\begin{array}{c}\text { Type of Customers PLN, } \\
\text { kVA }\end{array}$ \\
\hline Fisheries & 146.00 & $2,538.00$ & 250 \\
\hline Plantation & 128.00 & $1,540.00$ & 250 \\
\hline Tourism & 569.15 & $7,946.27$ & 1,000 \\
\hline Total & $\mathbf{8 4 3 . 1 5}$ & $\mathbf{1 2 , 0 2 4 . 2 7}$ & $\mathbf{1 , 5 0 0}$ \\
\hline
\end{tabular}

The planning of PLTS hybrid generator aims to reduce diesel oil consumption by utilizing the potential of solar energy which is $5,0 \mathrm{~kW} / \mathrm{m}^{2} /$ day with equivalent 5 Sun Hours. The planned power plant must be able to supply a maximum load of $844 \mathrm{~kW}$ and electrical energy of $12,025 \mathrm{kWh} /$ day. With the current technology, the maximum PV penetration in a hybrid PLTD-PLTS system is $60 \%$ peak load. With this system the electrical energy generated by the PLTS is directly supplied to the load so that the PLTS only serves to reduce the supply of generators when the sun is there or in other words reduce fuel consumption generator set. While there is no sunlight, the load is entirely borne by the generator set.

The solar panel used as material for this analysis is $255 \mathrm{Wp} 30.7 \mathrm{~V}$-DC with $15.5 \%$ efficiency. Planned PLTS capacity of $20 \%$ of the peak load during the day is $844 \mathrm{~kW}$, which is $169 \mathrm{kWp}$. Using the same methodology by calculating the PLTS components above, the number and capacity of solar panels, PV inverter capacity and generator capacity calculated. All panel components are the same as the components in the PLTS design, except for the inverter, which have a lower capacity of $20 \mathrm{~kW}$ and an input voltage rate of $580 \mathrm{~V}$ and MPP voltage ranges between $580-800 \mathrm{~V}$-DC. The number of PV inverters used is one inverter. The calculation results can be seen in Table below.

Table 7. Generating system component of PLTS Hybrid with Generator or PLTD (20:80)

\begin{tabular}{|c|c|c|c|c|c|}
\hline \multirow{2}{*}{$\begin{array}{c}\text { No } \\
1\end{array}$} & \multicolumn{5}{|c|}{ Component of Power Generation } \\
\hline & SOLAR PANELS & & & & \\
\hline & Spesification of PLTS & & & & \\
\hline & Panel PV Capacity & 255 & Wp & & \\
\hline & Panel PV Voltage & 30.7 & Vdc & & \\
\hline & Efficiency of PV Inverter & 98.4 & $\%$ & & \\
\hline & Efficiency of battery Inverter & no battery & $\%$ & & \\
\hline & Efficiency of battery & no battery & $\%$ & & \\
\hline & Depreciation PV Power & 90 & $\%$ & & \\
\hline & & 88.56 & $\%$ & & \\
\hline & $20 \%$ capacity of demand PLTS & 169 & kW & & \\
\hline & System of Panel Capacity PLTS & 190.4 & kW & & \\
\hline & Potency of radiation in Sitaro & 5 & $\mathrm{~kW} / \mathrm{m} 2 / \mathrm{day}$ & & \\
\hline & Production of Energy per day & 952.07 & $\mathrm{kWh} / \mathrm{day}$ & & \\
\hline & Power Capacity PLTS & 190.4 & $k W p$ & 191 & $k W p$ \\
\hline & Number of Panel PLTS & 746.72 & Panels & 747 & Panels \\
\hline \multirow[t]{10}{*}{2} & INVERTER PV & & & & \\
\hline & Spesification of Inverter PV & & & & \\
\hline & Capacity & 25 & kW & 191 & $\mathrm{~kW}$ \\
\hline & Input Vdc rate & 600 & Vdc & & \\
\hline & Number of Inverter PV & 7.64 & units & 8 & Units \\
\hline & Number of Panel PV per Inverter & 94 & & & \\
\hline & PLTS series & 20 & & & \\
\hline & Parallel & 5 & & & \\
\hline & Correction of Numbers PLTS & 764 & units, Capac & 194.82 & $k W p$ \\
\hline & Correction of Energy Production PI & 862.66 & kWh/day & & \\
\hline \multirow[t]{8}{*}{3} & GENERATOR SET & & & & \\
\hline & Spesification & & & & \\
\hline & Capacity & 1,000 & kVA & & \\
\hline & Spesific Fuel Consumption SFC & 0.286 & litre/kWh & & \\
\hline & Required of Energy Generation per & $11,161.61$ & kWh/day & $4,073,988$ & $\mathrm{kWh} /$ year \\
\hline & Diesel Oil Consumption per day & 3,195 & litre/day & & \\
\hline & Diesel Oil Price & 8,800 & Rp/litre & & \\
\hline & & & & & \\
\hline
\end{tabular}

We can see from the table 7, Hybrid system of power generating using $20 \%$ of PLTS and $80 \%$ of PLTD indicates the number of solar panels is 764 units and PLTS Power Capacity is $194 \mathrm{kWp}$ with a daily 
production of $862.66 \mathrm{kWh} /$ day. The number of inverters is eight units with 94 panels / inverter. Generator capacity is 1000 kVA with SFC 0,286 liters / kWh, Energy generated per day 11,161.61 kWh / day with fuel consumption of 3,195 liters / day.

\section{Calculation of PLTS Hybrid Costs}

The cost of PLTS hybrid energy is calculated using the Life Cycle Analysis method, which is a comparison of the total cost used to produce energy with the amount of energy produced during the life of the PLTS. The initial investment cost of PLTS hybrid for this system is divided into the cost of the PV system and the cost of the Generator system. The details of the initial investment costs of $194 \mathrm{kWp}$ PLTS and $1000 \mathrm{kVA}$ generator system are shown in Table below.

Table 8. The Initial Investment cost of PLTS Hybrid

\begin{tabular}{|c|c|c|c|c|}
\hline Component & Quantity & Unit & Price, $R p$ & Total Price, Rp \\
\hline Generator set 1000 kVA & 1 & Unit & $3,764,880,000$ & $3,764,880,000$ \\
\hline $\begin{array}{c}\text { Installation, powerhouse and } \\
\text { accessories }\end{array}$ & 1 & Unit & $1,129,464,000$ & $1,129,464,000$ \\
\hline Power at STC $255 \mathrm{Wp}$ & 754 & Unit & $6,160,000$ & $4,706,240,000$ \\
\hline SMA Sunny Tri-power STP 25000TL-30 & 8 & Unit & $59,803,800$ & $478,430,400$ \\
\hline $\begin{array}{c}\text { Balance of Systems (BoS), 35\% of Total } \\
\text { Utility }\end{array}$ & 1 & Set & $1,814,634,640$ & $1,814,634,640$ \\
\hline Total & & & & $11,893,649,040$ \\
\hline$* 1 \mathrm{USD}=\mathrm{Rp} 13,500$ & & & $\mathrm{Rp} / \mathrm{kWp}$ & $61,049425,32$ \\
\hline
\end{tabular}

The total initial investment cost is Rp.11,893,649,040. The cost of PLTS system is the biggest cost reaching around $60 \%$ of the total investment cost, and the Generator system cost is $40 \%$. In the PLTS Hybrid, there are 4 components of operational and maintenance costs: O\&M PLTS, inverter replacement costs, O\&M Generator costs and fuel costs. Assuming an operating period of 25 years and a fixed rate of $4.25 \%$, the calculation shown that the COE of the $20 \%$ Hybrid PLTS + Generator is Rp.2,801.02 / kWh or 20.75 cent \$ US / kWh.

Therefore, the calculation the contribution of PLTS and Generator in the PLTS Hybrid system seen in the table below.

Table 9. The Contribution of PLTS and Generator in the PLTS Hybrid System

\begin{tabular}{|l|c|c|c|c|c|}
\hline \multirow{2}{*}{$\begin{array}{l}\text { Supply of Energy } \\
\text { PLTS Hybrid }\end{array}$} & \multicolumn{4}{|c|}{ Component of Cost } & $\begin{array}{c}\text { Rp/ } \\
\text { Investment }\end{array}$ \\
\cline { 2 - 5 } & Fuel & O\&M & Others & kWh \\
\hline $\begin{array}{l}\text { PLTS 20\%/ } \\
199.92 \mathrm{kWp}\end{array}$ & $11,893,649,040$ & $141,206,921,647$ & $23,478,210,284$ & $1,107,789,100$ & 2,801 \\
\hline $\begin{array}{l}\text { PLTS } 40 \% / \\
398.82 \mathrm{kWp}\end{array}$ & $18,859,690,080$ & $130,350,400,214$ & $23,842,419,522$ & $2,215,578,199$ & 2763 \\
\hline $\begin{array}{l}\text { PLTS } 20 \% / \\
\text { 597.66 kWp }\end{array}$ & $25,778,259,990$ & $119,436,739,195$ & $24,184,224,093$ & $3,184,893,662$ & 2,720 \\
\hline
\end{tabular}

Based on the calculation above, the increasing of PLTS capacity will reduce the cost of energy. It shows that the lowest of COE is $60 \%$ PLTS and $40 \%$ Generator. The COE is Rp.2720,58/kWh or 20.15 cent \$US/kWh.

\section{Conclusions}

The main issues in the development of isolated area is the limited basic infrastructure include energy sectors. The important things of developing infrastructure of energy is sufficient, secure, reliable, and affordable for users or society. In order to achieve the goals, identification of local energy potential demand of energy, current productive economy, current system of electricity, and infrastructure of 
energy are vitals aspects. The case study in the region of Sitaro Island, North Sulawesi can be represent of Sustainable Development of Energy Supply Planning For Productive Economy in Isolated Island.

System of electricity in Sitaro Islands had installed capacity $11,610 \mathrm{~kW}$ which is provided by PT. PLN. It consists of four electricity systems namely Siau System, Makalehi System, Tagulandang System and Biaro System. Electricity system in Sitaro is powered by diesel power generation (PLTD). The local potential of energy resources is photovoltaic with intensity of radiation $5,0 \mathrm{kWh} / \mathrm{m} 2$ per day. The demand of energy of Islands is primary for lighting, ironing, and entertainment. The top three economy of islands based on Gross Domestic Product is dominated by fisheries, agriculture, and hotel tourism (BPS, 2020). The existing conditions, the only available fuel source is diesel oil (PLTD), while for renewable energy is only from solar energy. Therefore, the generation scenarios are hybrid generation between PLTS and PLTD that will be connected in grid PLN. The solar panel used as material for this analysis is $255 \mathrm{Wp} 30.7 \mathrm{~V}$-DC with $15.5 \%$ efficiency. Based on the calculation, the increasing of PLTS capacity will reduce the cost of energy, which the lowest of COE is $60 \%$ PLTS and $40 \%$ Generator. The COE is Rp.2,720.58/kWh or 20.15 cent USD/kWh.

\section{Acknowledgments}

We thanks to the support from all partners that make this paper is submitted. Thanks to The head of Research and Development Centre for Electricity Renewable Energy and Conservation Technology, Ministry of Energy and Mineral Resources, Researchers of Electricity Group, and Local government of Sitaro Islands.

\section{References}

Bien, L.E., Kasim, L, Wibowo, W. (2008). Perancangan Sistem Hibrid Pembangkit Listrik Tenaga Surya dengan Jala-jala Listrik PLN untuk Rumah Perkotaan. JETri Volume 8. No. 1 : 37-56.

BPS. (2020). Kabupaten Kepulauan Siau Tagulandang Biaro Dalam Angka 2019. Kabupaten Kepulauan Siau Tagulandang Biaro

BLU P3TEK. (2018). Laporan Proyek Pemasangan PLTS Rooftop di Gedung BPH Migas

Denholm, P., and Margolis, R. (2006). Very Large-Scale Deployment of Grid-Connected Solar Photovoltaics in the United States: Challenges and Opportunities. Conference Paper NREL/CP-620-39683.

Direktorat Jenderal Ketenagalistrikan, Kementerian ESDM. (2019). Statistik Ketenagalistrikan 2019. Jakarta

Halim, A. (2009). Analisis Kelayakan Investasi Bisnis. Yogyakarta : Graha Ilmu.

Joule Bergerson and Lester Lave. (2004). Life Cycle Analysis of Power Generation Systems. Encyclopedia of Energy. Pages 635-645

Marulitua Situmorang, Dokman \& Ayustia, Rissa. (2019). Model Pembangunan Daerah 3T: Studi Kasus Daerah Perbatasan Kabupaten Bengkayang. MBIA. 18. 49-64. 10.33557/mbia.v18i1.321.

Mermoud, A and Lejeune, T. (2010). Performance Assessment of A Simulation Model for PV Modules of Any Available Technology. 25th European Photovoltaic Solar Energy Conference - Valencia, Spain

Messenger, R.A. (2005). Ventre, J. Photovoltaic Systems Engineerin, 2nd edition, Boca Raton, FL, CRC Press.

Ministry of Energy and Mineral Resources. (2019). Keputusan Menteri ESDM Nomor 1567 K/21/MEM/2018 tentang Pengesahan Rencana Usaha Penyediaan Tenaga Listrik (RUPTL) PT PLN (Persero) Tahun 2018 s.d. 2027.

Ministry of Energy and Mineral Resources. (2018).Peraturan Menteri ESDM No. 49 tahun 2018, tentang Penggunaan Sistem Pembangkit Listrik Tenaga Surya atap oleh Konsumen PT Perusahaan Listrik Negara (Persero)

Widayana G. (2012). Pemanfaatan Energi Surya. JPTK, UNDIKSHA, Vol. 9, No. 1, Januari 2012: 37 - 46 